\title{
Bacterial Dynamics in a Microphytobenthic Biofilm: a Tidal Mesocosm Approach
}

\author{
Hélène Agogué ${ }^{a, *}$, Clarisse Mallet ${ }^{b}$, Francis Orvain ${ }^{c},{\text { Margot De } \text { Crignis }^{\mathrm{a}, \mathrm{c}} \text {, Françoise Mornet }}^{\mathrm{d}}$, \\ Christine Dupuy ${ }^{\mathrm{a}}$
}

\footnotetext{
a UMR 7266 CNRS - Laboratoire LIENSs, Université de La Rochelle, 2 rue Olympe de Gouges, 17000 La Rochelle cedex, France

b Laboratoire Microorganismes: Génome et Environnement, UMR 6023 CNRSUniversité de Clermont-Ferrand II, 24 avenue des Landais, 63177 Aubière Cedex, France

' Université de Caen Basse-Normandie, FRE3484 BioMEA CNRS, Esplanade de la Paix, 14032 Caen, France

' Laboratoire Ressources Halieutiques de La Rochelle, Ifremer - Station de La Rochelle - Place Gaby Coll - BP 7 17137 L'Houmeau, France
}

\author{
*: Corresponding author : Hélène Agogué, tel.: + 33546507650 ; fax: + 33546507663 : \\ email address : helene.agogue@univ-Ir.fr
}

\begin{abstract}
:
In intertidal mudflats, during low tide exposure, microphytobenthos (MPB) migrate vertically through the surface sediment and form, with the heterotrophic bacteria, a transient biofilm. Inside this biofilm, multiple interactions exist between MPB and bacteria. These micro-organisms secrete a wide range of extracellular polymeric substances (EPS), which are major components of the biofilm matrix. In this study, we used a tidal mesocosm experiment in order to decipher the interactions of the MPB-EPSbacteria complex within the biofilm. We tried to determine if the EPS could control bacterial activities and/or production and/or richness according to the age of the biofilm and to the immersion/emersion period. The dynamics of biomasses of MPB and prokaryotes, the bacterial production, the hydrolysis of predominating organic constituents in the dissolved organic carbon (DOC) pool (i.e., carbohydrates and polypeptides), and the bacterial structure were studied in relation to the different EPS fractions (carbohydrates and proteins: colloidal and bound) dynamics during 8 days. Our experiment had emphasized the influence of the environmental conditions (light, immersion/emersion) on the interactions within the biofilm and also on the effects on biofilm ageing. Bacterial production was always inhibited by the bound EPS-carbohydrate, especially during low tide. Our results suggest that the concentration and composition of EPS had a major role in the bacterial/MPB interactions: these interactions can be either positive or negative in order to regulate the productive phases of MPB and bacteria.
\end{abstract}

\section{Highlights}

concentration and composition of EPS have a major role in the bacterial/microphytobenthos interactions - EPS are regulating negatively or positively the productive phase of microphytobenthos and bacteria EPS are controlling bacterial activities, production and richness according to the age of the biofilm and to the immersion/emersion period colloidal EPS protein are favorable to the bacterial enzymatic activities bacterial production is inhibited by EPS carbohydrates, especially during low tide

Keywords : Muddy Sediment ; Microphytobenthos ; Bacteria ; Extracellular Polymeric Substances ; Interactions ; Mesocosm 


\section{Introduction}

Intertidal mudflats are highly productive ecosystems associated with estuaries and semi-enclosed bays. In western Europe, these geomorphological structures are mostly devoid of macrophytes, but nevertheless exhibit high primary productivity due to the presence of microphytobenthos (MPB) mainly composed of epipelic diatoms (MacIntyre et al., 1996; Underwood and Kromkamp, 1999). Many works on mudflats also demonstrated that the bacterial production showed high rates, especially in summer and autumn (Cammen, 1991; Hamels et al., 2001; Pascal et al., 2009; van Duyl and Kop, 1990) and bacterial abundance may be equivalent to billions of cells by $\mathrm{mL}$ of mudflat sediment (Pascal et al., 2009; Smith and Underwood, 1998).

During low tide exposure, MPB migrate vertically through the sediment to the surface and form with the heterotrophic prokaryotes, a transient biofilm (Consalvey et al., 2004; Herlory et al., 2004). Inside this biofilm, multiple interactions exist between MPB and prokaryotes (Makk et al., 2003). The MPB and prokaryotes secrete a wide range of extracellular polymeric substances (EPS) which are major components of the biofilm matrix. Epipelic diatoms secrete 30-60\% of photoassimilated carbon as EPS into the surrounding sediment (Middelburg et al., 2000; Smith and Underwood, 2000; Underwood et al., 1995). These EPS are rich in polysaccharides, proteins, proteoglycans, lipids and many other compounds expressed at different contents (Chiovitti et al., 2003; Pierre et al., 2010; Pierre et al., 2012; Underwood et al., 2004). The types of EPS are related to the location and/or environmental conditions which affect food webs, the primary production of this ecosystem, and sediment properties (Underwood and Paterson, 2003). Polymer chemistry and surface properties of EPS affect coagulation and aggregation (Bhaskar et al., 2005), pore water content (Potts, 1994) and ion binding (Chin et al., 1998). Furthermore, EPS can act as a kind of glue stabilizing whole sediments and help mitigate surface sediment losses (Decho, 2000; Lubarsky et al., 2010; Stal and de Brower, 2003; Sutherland et al., 1998; Underwood and Paterson, 2003). EPS are also involved in the motility system and substratum adhesion of epipelic diatoms (Higgins et al., 2003; Stal and Défarge, 2005; Wustman et al., 1997). EPS consist of two fractions: colloidal and bound EPS. Recently, Takahashi et al. (2009) have optimized a protocol for bound EPS extraction and proposed an innovative method (Dowex), to extract EPS without any contamination by internal compounds. Bound EPS are especially rich in deoxy sugars compared to other fractions, but deoxy sugars are known to be a 
unfavorable substrate for bacteria that select other sources of carbon like glucose (Giroldo et al., 2003).

Concerning the interaction between MPB and prokaryotes, the photosynthetically fixed carbon by the MPB is transferred towards bacteria in few hours, translating a quick use from sources of labile carbon, possibly including EPS (Cook et al., 2007; Goto et al., 2001; Middelburg et al., 2000; Underwood and Paterson, 2003). Bellinger et al. (2009) showed, in a ${ }^{13} \mathrm{C}$-tracer study of estuarine biofilms, that the photosynthetically fixed carbon by the biofilm community was incorporated within 4 hours into diatom intracellular storage carbohydrates, extracellular polysaccharides, and into Gram-negative bacterial PLFAs (phospholipid fatty acids) through heterotrophic utilization of EPS.

On mudflats, correlative studies of algal, bacterial, and enzymatic activity suggest that some degree of algal-bacterial coupling does occur (Haynes et al., 2007). Moreover, Yallop et al. (2000) found a significant correlation between MPB biomass and bacterial production. In Marennes-Oléron bay, a survey conducted in 2008 revealed contrasting results according to the season (Orvain et al., This Issue). In summer, there was a high level of correlation between bacteria and MPB biomasses coinciding with a secretion of colloidal EPS and a high proportion of bound EPS-protein $(-10 \%)$. In winter, the MPB biomass was higher and there was an opposition between phases of MPB growth and bacterial growth that seems to be related to a high secretion rate of bound EPS and the absence of EPS-protein at this season. A potential role of inhibition caused by bound EPS-carbohydrates was evoked, but such an assumption must be verified in controlled conditions.

Bacteria play an active role in the production of dissolved organic carbon (DOC) from particles particularly originating from primary production via exoenzymatic activities (Hoppe, 1984; Smith et al., 1992). In mudflat sediment, hydrolysis process and the extracellular enzyme activities of bacteria can convert bound EPS into colloidal EPS (Hanlon et al., 2006). Bacteria can produce exoglucanases such as the glucosidase enzymes in order to cleave the $\alpha$ and $\beta$ - linkages of combined carbohydrates (Sutherland, 1999) and exopeptidases such as the leucine amnipeptidase to hydrolyse polypeptides and proteins (Gonzales and RobertBaudouy, 1996). Nevertheless, the regulation of these activities depends on the composition of the organic matter (type and quantity of compounds) and environmental conditions ( $\mathrm{pH}$, temperature, ions) which can induce, inhibit, or suppress them (Boetius and Lochte, 1994, 1996; Chróst and Overbeck, 1990). However in the case of nutrient deficiency, MPB is in competition with bacteria and the growth of bacteria remains limited (Waksman and Butler, 1937). In spite of strong levels of organic matter in muddy sediments, a correlation between 
algal production and exoenzymatic activities of bacteria was highlighted during field studies (Hanlon et al., 2006; van Duyl et al., 1999) and during experimentation on diluted sediment (Goto et al., 2001; Haynes et al., 2007; Thornton et al., 2010). Concerning the structure of the bacterial community, some studies suggest that algal-bacterial coupling in estuarine sediments is likely to involve particular taxa rather than a response from the entire bacterial community (Amin et al., 2012; Bellinger et al., 2009; Hanlon et al., 2006; Haynes et al., 2007).

Mudflats are highly dynamic environments (MacIntyre et al., 1996; Underwood and Kromkamp, 1999). Multiple variables are at play and complex ecological relationships may mask the signal associated with the interactions of the MPB-EPS-Bacteria complex. Owing to the possibility of achieving a good balance among control, realism and generality (Kemp et al., 2001; Petersen et al., 2003), mesocoms are well suited for the study of interspecific interactions within the biofilm. Mesocosms have proven to be appropriate tools to study the impact of nutrients deficiency and biofilm age on the composition of EPS secreted by the microorganisms (Blanchard et al., 2001; Orvain et al., 2003; Staats et al., 2000b).

In our study, the use of tidal mesocosm provides a limited quantity of sediment, in which environmental factors (such as temperature, light, predators, and tides) can be wellcontrolled. Our experimental system allows us to study the interaction within the biofilm age (composition and concentration of EPS secreted by microorganisms) and the immersion/emersion period, The biomasses of algae and prokaryotes, the bacterial production, the enzymatic activity rates by bacterial communities (i.e., $\alpha$ - and $\beta$-glucosidase and the aminopeptidase) and the bacterial diversity were followed as well as the dynamics of the EPS (colloidal and bound) during 8 days in this tidal mesocom.

\section{Materials and methods}

\subsection{Sampling area and experimental mesocosm}

We first collected a large amount of sediments $\left(1 \mathrm{~m}^{3}\right)$ from the Esnandes mudflat located in the northern part of the Aiguillon Bay, France $\left(46^{\circ} 15^{\prime} 18.00^{\prime \prime} \mathrm{N}, 1^{\circ} 8^{\prime} 30.20 " \mathrm{~W}\right)$. The sediment was sieved by hand, without adding seawater and using $1 \mathrm{~mm}$ sieve, to exclude macrofauna (i.e., grazers). Two weeks later, in similar tidal conditions, we collected fresh sediments from the same site (only the top $2 \mathrm{~mm}$ surface sediment, in areas with visible biofilms - i.e $10 \mathrm{~m}^{2}$ ). Ten liters of enriched sediment were brought back to the lab and this fluid superficial sediment was immediately filtered to remove macrofauna and applied on four 
sediment plates $(20 \times 30 \mathrm{~cm})$, with eight nylon nets $(100 \mu \mathrm{m}$ mesh size, Buisine, France) over the surface (not lens tissues). Two folds of nylon nets were put over the surface of each plate and exposed to artificial lights during 24h. On the following day, the top net was collected and mixed in 5L of artificial seawater. Microphytobenthic algae settled rapidly and the supernatant was discarded after $10 \mathrm{~min}$ to keep $50 \mathrm{ml}$ of the pellet containing a concentrated mixture of MPB. This mixture was immediately used as an inoculum that was added to $20 \mathrm{~L}$ of sediment collected from the previously-prepared sediment (and from which water content was measured one day before). Eighty four $\mathrm{ml}$ of water per liter of sediment was precisely added to the inoculum in order to match the water content of superficial sediment in the field (i.e., 65\%) (Orvain et al., This Issue). The enriched sediment was mixed and a layer of $1 \mathrm{~cm}$ was deposited in each experimental core (height: $15 \mathrm{~cm}$; diameter: $5 \mathrm{~cm}$ ) over a sub-layer of $20 \mathrm{~cm}$ of compact sediment without MPB (i.e the same sediment stock that was previously prepared but without addition of inoculum).

Cores were maintained in experimental mesocosm connected to a recirculating filtered seawater system, with a tidal simulation ( 2 tides per day), at a temperature of $20 \pm 1.3{ }^{\circ} \mathrm{C}$ and a light $\left(993 \pm 300 \mu \mathrm{mol} \cdot \mathrm{m}^{-2} \cdot \mathrm{s}^{-1}\right)$, dark regime of $12 \mathrm{~h}$ and $12 \mathrm{~h}$, respectively. Monitoring of irradiance (Licor captor) and air, air/water and sediment temperatures (Hobo captor) were made during all the mesocosm experiment (8 successive days) (Fig. 1). Salinity of the sea water was measured 4 times during the experiment (Fig. 1).

One 6h-daytime air exposure period and one 6h-night time air exposure were reproduced in the mesocosm between $9 \mathrm{AM}$ and $3 \mathrm{PM}$ and $9 \mathrm{PM}$ and $3 \mathrm{AM}$ respectively. Outside these times, sediments were covered with seawater in the light during the day (from 3 $\mathrm{PM}$ to $9 \mathrm{PM}$ ) and in the dark during the night (from $3 \mathrm{AM}$ to $9 \mathrm{AM}$ ). The sampling was done each day at the end of high night tide (7:30 AM), at the beginning (10:30 AM) and the end (1:30 PM) of low day tide and beginning of high day tide (4:30 PM). For each sampling, three individual cores were randomly chosen, and the first $\mathrm{cm}$ of the surface of the 3 cores was collected, pooled, mixed, and then analyzed as below.

\subsection{Others abiotic parameters}

For nutrient analysis, interstitial water from the sediment was filtered immediately after centrifugation $\left(3500 \mathrm{~g}, 4^{\circ} \mathrm{C}, 10 \mathrm{~min}\right)$ through $0.2 \mu \mathrm{m}$ cellulose nitrate filters. Half of the volume was immediately assayed using the colorimetric Koroleff (1969) technique for ammonium measurement. The remainder was stored at $-20^{\circ} \mathrm{C}$ until analysis of other nutrients. 
Phosphates were assayed using a Skalar automated segmented flow analyzer with classical spectrocolorimetric techniques (protocols adapted from Tréguer et al. (1979)). Nutrient analyses were carried out using a Technicon III - Bran Luebbe Analyste. The pore water content of the sediment was measured by difference between the wet weight and the dry weight (after freeze-drying).

The EPS extraction was done immediately after sampling and sediment mixing with artificial seawater for colloidal fraction and dowex resin for bound fraction (Orvain et al., This Issue; Pierre et al., 2010; Takahashi et al., 2009). For each fraction (colloidal and bound) of EPS, total sugar content was determined using the phenol-sulfuric acid assay with glucose as a standard (Dubois et al., 1956), and protein content was determined using the Lowry assay with bovine serum albumin (BSA) as a standard (Lowry et al., 1951).

\subsection{Biotic parameters}

\section{Chlorophyll a}

Algal biomass in sediment was assessed using chlorophyll $a$ as a proxy and measured using fluorometry (Lorenzen, 1966) after extraction from weighed freeze-dried sediment in $90 \%$ acetone at $4^{\circ} \mathrm{C}$ overnight and centrifugation $\left(3500 \mathrm{~g}, 5 \mathrm{~min}, 4^{\circ} \mathrm{C}\right)$.

\section{Prokaryotic abundance}

For the determination of the abundance of prokaryotic organisms, sediment $(2 \mathrm{~mL})$ was fixed by $0.2 \mu \mathrm{m}$ filtered formaldehyde (final concentration $2 \%$ ) and stored at $4{ }^{\circ} \mathrm{C}$ until analysis. To separate bacteria from sediment particles, incubation in pyrophosphate $(0.01 \mathrm{M}$ during at least $30 \mathrm{~min}$ ) and sonication (60W) were performed (Pascal et al. (2009). Bacteria were labeled using 1.6-diamidino-2-phenylindole dihydrochloride (DAPI) (2500 $\mu \mathrm{g} . \mathrm{l}^{-1}$ ), filtered onto $0.2 \mu \mathrm{m}$ Nucleopore black filter (Porter and Feig (1980) and then counted by microscopy (x 1000, Axioskop 2 - Zeiss). The cell sizes (length and width) were measured on at least 100 cells through a calibrated ocular micrometer. From cell size measurements, the mean cell volume $\left(0.40 \mu \mathrm{m}^{3}\right)$ was calculated by equating $V=\pi r^{2}$. (L-2/3 r) (Fuhrman, 1981). The volume was converted into carbon units by using a theoretical carbon/volume ratio of 220 fgC $\mu \mathrm{m}^{-3}$ (Bratbak and Dundas, 1984).

\section{Bacterial production}


Bacterial production was estimated by the $\left[{ }^{3} \mathrm{H}\right]$ methylthymidine (TdR) incorporation method (Fuhrman and Azam, 1982) modified by Pascal et al. (2009). Rates of ${ }^{3} \mathrm{H}$-thymidine incorporation were transformed to cell production using a conversion factor of $1.9637 \times 10^{17}$ cells produced per mole of thymidine incorporated. This conversion factor was experimentally determined in batch experiments where the increase of bacterial abundance and ${ }^{3} \mathrm{H}$-Thy incorporation were simultaneously followed (data not shown). Cellular production was multiplied by the average cell carbon content of $89 \mathrm{fg} \mathrm{C}^{-1} \mathrm{cell}^{-1}\left(0.40 \mu \mathrm{m}^{3}\right.$

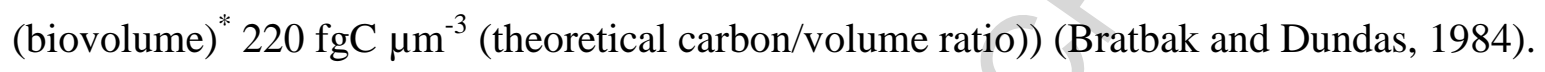

\section{Potential exoenzymatic activities}

Measurements of potential $\alpha$ and $\beta$-glucosidase and leucine aminopeptidase activities in sediment were performed respectively in Mallet and Debroas $(1999,2001)$ with slight modifications. Sediment slurry was prepared using the sediment, diluted to $1 / 1$ with sterile 0.2 $\mu \mathrm{m}$ filtered seawater. The saturating concentrations used were $1 \mathrm{mM}$ for $\alpha$ and $\beta$-glucosidase activities and $50 \mu \mathrm{M}$ for leucine aminopeptidase activity. Control and triplicates were incubated during 45, 75, and 120 min for $\alpha$ and $\beta$-glucosidase activities and 10, 30, and 60 min for leucine aminopeptidase activity at in situ mesocosm temperature. At the end of the incubation, the samples were centrifuged $\left(10000 \mathrm{~g}, 2 \mathrm{~min}, 4^{\circ} \mathrm{C}\right)$. Stop solution was added to the resulting supernatant: ammonium-glycin buffer $(0.05 \mathrm{M}$ of glycin and $0.2 \mathrm{M}$ of ammonium chloride; $\mathrm{pH}$ of 10.5-11) for $\alpha$ and $\beta$-glucosidase activities and $10 \%$ SDS solution for leucine aminopeptidase activity. Tubes were stored at $-20{ }^{\circ} \mathrm{C}$ until analysis. The fluorescence was measured with a spectrofluorimeter (SAFAS FLXXenius) at excitation 365 $\mathrm{nm}$ and emission $460 \mathrm{~nm}$ for $\alpha$ and $\beta$-glucosidase activities and excitation $340 \mathrm{~nm}$ and emission $410 \mathrm{~nm}$ for aminopeptidase. Solutions of 4-methylumbelliferone (0 to $1 \mu \mathrm{M})$ for $\alpha$ and $\beta$-glucosidase activities and 2-naphtylamine ( 0 to $12.5 \mu \mathrm{M}$ ) for aminopeptidase activity, freshly prepared with slurry sediment, were used as standards.

\section{Diversity of bacteria}

Genomic DNA from $650 \mathrm{mg}$ of sediment was extracted and purified using the Ultra Clean Soil DNA isolation kit (MoBio Laboratories) according to the manufacturer's instructions for maximum yields. Genomic DNA from water was extracted on filter $(100 \mathrm{~mL})$ and purified by the standard alkaline lysis method (Pesce et al., 2006). DNA quality was checked by $1 \%(\mathrm{w} / \mathrm{v})$ agarose gel electrophoresis and quantified using NanoDrop. The 
bacterial (V6-V8 regions) 16S rDNA genes were PCR-amplified using, respectively, the primers GC-968f and 1401r (Heuer and Smalla, 1997). The PCR mix (50 $\mu$ L) contained 1X PCR buffer, $2.5 \mathrm{mM} \mathrm{MgCl}$, $200 \mathrm{mM}$ of each dNTP, 20 pmol of each primer, $250 \mathrm{ng} \mathrm{mL}-1$ of bovine serum albumin (BSA, Sigma), 1.5 units of HotStart Taq DNA polymerase (Qiagen), and $30 \mathrm{ng}$ of sediment DNA extract. The samples were amplified in an iCycler thermocycler (Bio-Rad) under the following programs: $95^{\circ} \mathrm{C}$ for $15 \mathrm{~min}, 35$ cycles at $97^{\circ} \mathrm{C}$ for $1 \mathrm{~min}, 58^{\circ} \mathrm{C}$ for $1 \mathrm{~min}$ and $72^{\circ} \mathrm{C}$ for $1 \mathrm{~min}$, and, finally, $72^{\circ} \mathrm{C}$ for $10 \mathrm{~min}$. PCR products were checked by $0.8 \%(\mathrm{w} / \mathrm{v})$ agarose gel electrophoresis and quantified using the DNA quantitation kit fluorescence assay (Sigma). The DNA of the samples of the last day of the experiment (i.e., D8) was not successfully amplified. DGGE analyses of PCR-16S rDNA gene products were performed on a D-Code Universal Mutation Detection System (Bio-Rad). $500 \mathrm{ng}$ of each PCR products was loaded onto $8 \%$ polyacrylamide (w/v) denaturating gels with linear gradients of $40-60 \%$ (100\% denaturant contains $7 \mathrm{M}$ urea and $40 \%$ formamide). Gels were run in 1X TAE buffer $(\mathrm{pH} 8)$ at a constant temperature of $60^{\circ} \mathrm{C}$ for $16 \mathrm{~h}$ at $70 \mathrm{~V}$. After electrophoresis, the DGGE gels were stained in 1X TAE buffer containing 1/20000 dilution of Gel Star (Lonza, Rockland, ME-USA) and digitized using BioSpectrumAC Imaging System (UVP). Numerical analysis of digitized gels was performed using the Gel ComparII software (Applied Maths, Kortrijk, Belgium). Total band intensity for each lane was normalized among lanes. A DNA band was considered if it accounted for more than $0.5 \%$ of the total lane intensity. The structure of bacterial communities was assessed by the richness (BR, i.e, bacterial richness) estimated as the number of bands.

\subsection{Statistical analysis}

Pairwise similarity matrices were calculated for the DGGE patterns using the Dice equation for presence/absence and the Bray-Curtis equation for relative peak height data. Dendrograms were generated from the Dice matrix as described by Ward (1963). The Student's t-tests were done using ExcelStat. T-tests were conducted to assess differences in means between low tide and high tide and to establish differences between values of the variables at the end and at the beginning of the emerged period. Correlation between biofilm variables was assessed by Pearson's correlation tests by using a F-test $(n=32)$.

\section{Results and discussion}

\subsection{Development of the microphytobenthic biofilm over an 8-day experiment}


The data of light were near the in situ summer measurements during the diurnal low tide with 1200 to $2000 \mu \mathrm{mol}$ photons $\mathrm{m}^{-2} \mathrm{~s}^{-1}$ (Fig. 1a) and the dark:light alternating cycles were well reproduce (Guarini et al., 2000). The air, air water and sediment temperature varied with the tidal cycle, increased from $24^{\circ} \mathrm{C}$ to $30^{\circ} \mathrm{C}$ during the low tide. At night, temperatures were lower, varying between 18 and $22^{\circ} \mathrm{C}$. Nutrients concentration decreased during all the experiment, and decreased often during the low tide (Fig. 1b). Ammonium concentration decreased from $600 \mu \mathrm{mol} . \mathrm{m}^{-2}$ to $<100 \mu \mathrm{mol} . \mathrm{m}^{-2}$, phosphates concentration from $700 \mathrm{nmol} . \mathrm{m}^{-2}$ to $<100$ nmol.m ${ }^{-2}$ at the end of the experiment. These nutrients were relatively stable and not limiting for the first 72 hours (days 1 through 3 ) of the experiment and then, starting the $4^{\text {th }}$ day through the $8^{\text {th }}$ day, decreased rapidly, suggesting strong limitation for MPB at the end of the experiment (Fig. 1b). Chlorophyll $a$, a proxy used for the estimation of the MPB biomass, presented a maximum (142.6 mg.m ${ }^{-2}$ ) the third day after the beginning of the high tide (Fig. 2). The evolution of the nutrients concentrations and the chlorophyll $a$ have allowed separating the experiment in two phases: 1) days 1 through 3 (from 0 to $72 \mathrm{~h}$ ): formation of a biofilm with photosynthetically active microphytobenthic cells and 2) starting the $4^{\text {th }}$ day through the $8^{\text {th }}$ day (from $72 \mathrm{~h}$ to $180 \mathrm{~h}$ ): a stationary phase of the MPB biofilm which began to degrade (Fig. 1b and 2). The biomass of chlorophyll $a$ was adequate for a biofilm development since the minimum biomass requirement of $25 \mathrm{mg} \cdot \mathrm{m}^{-2}$ was achieved (Guarini et al., 2000). The chlorophyll $a$ concentration was similar to those observed on other mesocosms studies (Orvain et al., 2003; Yallop et al., 2000). With a mean of $109.5 \pm 14.6 \mathrm{mg} . \mathrm{m}^{-2}$, this was 2 times higher than the $59 \pm 10.4$ mg.m² observed in in situ summer (Orvain et al., This Issue). The differences are due to the grazing influence of gastropods observed in the summer (Orvain et al., This Issue).

\subsection{Dynamic of the biofilm formation}

There was no significant change between the concentration of chlorophyll $a$ at low tide and at high tide (Table 1). Within a low tide, colloidal carbohydrates were produced and particularly during the phase of the biofilm formation than the phase of the stabilization of the biofilm (Fig. 3a, Table 2). This increase in carbohydrate concentration at low tide was already mentioned in few studies (Bellinger et al., 2009; Hanlon et al., 2006; van Duyl et al., 1999) . This is due to an increase of the production of carbohydrates per cell and not an increase of the diatoms biomass in the first $\mathrm{cm}$ of the sediment (i.e, the chlorophyll $a$ concentration was 
stable) in the absence of overlying water (Fig. 3b). This confirmed that the production of carbohydrates was directly correlated to photosynthesis activities and thus to light (Smith and Underwood, 1998; Staats et al., 2000a; Underwood et al., 2004). The MPB biomass was stable during the light period, the fixed carbon is therefore predominantly excreted in the form of extracellular carbohydrates while little is used for balance growth (de Brouwer and Stal, 2001). During this first phase, at low tide, contrary to the chlorophyll $a$ concentration, the concentration of bound EPS-carbohydrates also increased (Fig. 3a-b). During the whole experiment, the concentration of bound EPS-carbohydrates was always higher compared to colloidal EPS-carbohydrates (1.5 to 4.5 times), with a mean of $259.4 \pm 55.0 \mathrm{mg}^{-2} \mathrm{~m}^{-2}$ (Fig. $3 \mathrm{a}$ ). It has been shown already that bound carbohydrates were, at some point, uncoupled from the diatoms biomass (Bellinger et al., 2009; Hanlon et al., 2006). Bound carbohydrates were positively correlated with chlorophyll $a$ and negatively with ammonium (Table 3). Bound EPS-carbohydrates seemed to be secreted by the active MPB during its growth phase as ammonium limitation tended to decrease the production of bound carbohydrates. The bound EPS-carbohydrates, once secreted by the diatoms, can become an integral part of the biofilm matrix and are likely a primary factor in biostabilization processes based on structural complexity and potential for being highly refractory (Chiovitti et al., 2003; Wustman et al., 1997). Concentrations of colloidal protein were higher at high tide during the first phase of the experiment (Table 1). EPS-protein concentrations were around 2.5 times higher compared to EPS-carbohydrate concentrations (Fig. 3a). Colloidal and bound EPS-protein presented similar concentrations from day 1 to day 4 (400 $\left.\mathrm{mg} \cdot \mathrm{m}^{-2}\right)$. The EPS-protein were more important during this first period playing a major role in pioneering stages and constitute the matrix of the biofilm and are accumulated continuously at the surface of the sediment (Gerbersdorf et al., 2009; Lubarsky et al., 2010; Orvain et al., This Issue; Yallop et al., 1994). EPS-protein can be secreted by diatoms but also by bacteria, that were really abundant during the first period, suggesting a potential synergic effect between the MPB and the bacteria during the formation of the biofilm. Synergistic effects between microalgae and bacteria have already been demonstrated in terms of EPS-protein secretion (Gerbersdorf et al., 2009; Lubarsky et al., 2010).

The diatoms and bacterial communities were highly active during the first phase. The biomass of bacteria was 2 or 3 times higher than MPB biomass (i.e., chlorophyll a) (Fig. 2). The bacterial production was higher during the first phase of the experiment and, converse to Van Duy et al. (1999), increased significantly at high tide (Table 1). With a low tide, the bacterial production tended to decrease especially at the beginning of the air/light exposure 
period (Fig. 2, Table 1). The bacterial biomass was significantly correlated to phosphate concentration (Table 3). MPB biomass (i.e., chlorophyll $a$ ) were negatively correlated to nutrients (phosphate and ammonium), while bacterial production was positively correlated to nutrients (Table 3). These data confirm that the nutrients play a major role in the development of prokaryotic communities, thus supporting greater abundances and production. Glucosidase activities tended to decrease during low tide, and this was more pronounced for the $\beta$ glucosidase activity (Fig. 4, Table 2). The aminopeptidase activity was quite stable during the low and the high tides around 4.2 $\pm 2.3 \mathrm{M} \cdot \mathrm{m}^{-2} \cdot \mathrm{d}^{-1}$ (Fig. 4, Table 1). The $\alpha$-glucosidase was positively correlated with MPB biomass and with the aminopeptidase, showing that these bacterial enzymatic activities, differing in their substrates (i.e., carbohydrates or proteins), had the same activity pattern in the biofilm (Table 3 ). The bacterial production was negatively correlated to MPB biomass and bound EPS-carbohydrate (Table 3). King (1986) and van Duyl et al. (1999) measured the activity of $\beta$-glucosidase in intertidal mudflats and demonstrated that benthic heterotrophic bacterial production depended on colloidal carbohydrates in a diatom biofilm-dominated mudflat. In our case, we showed that various bacterial variables such as bacterial production and enzymatic activities depended also on bound EPS-carbohydrates.

Concerning the bacterial structure, the formation of the biofilm (i.e., D1-D4 period) showed a higher richness during high and low tides (Table 1). A cluster analysis of the banding patterns was expressed as dendrograms. The cluster analysis of all the samples highlighted that there was a strong shift in bacterial structure during the day 4 (data not shown). Therefore another cluster analysis was applied with samples of each phase (D1-D4 period and D5-D7 period, respectively) (Fig 5). D1-D4 samples clustered in two distinct groups (similarity level < 85\%) including D1-D3 samples and D4 samples respectively (Fig. 5A). The bacterial richness was correlated to bound and colloidal proteins (Table 3). Few studies suggest that algal-bacterial coupling in estuarine sediments is likely to involve particular taxa rather than a response from the entire bacterial community (Bellinger et al., 2009; Hanlon et al., 2006; Haynes et al., 2007). For instance, Hanlon et al. (2006) have demonstrated that only a few bacterial OTUs were significantly correlated with the production of EPS by diatoms. In this study, the higher richness observed during the first phase of the development of the biofilm could be due to the development of specific bacterial populations (such as Gram - bacteria) involved in rapid utilization of EPS excreted quickly after photoassimilation by diatoms (Bellinger et al., 2009; Haynes et al., 2007). 


\subsection{Dynamic of the biofilm during its degradation}

After 4 days of active growth, the MPB biofilm was mature and started to degrade (Fig. 2) (D4-D8 period). Various stresses appeared including nutrient limitation (Fig. 1) and self-organized degradation of the biofilm associated with space and nutrients competitions (Weerman et al., 2010; Yallop et al., 1994). The concentration of colloidal EPS-carbohydrate was decreasing and, with the low tide, a significant decrease of production of bound EPSprotein appeared (Table 2). The secretion of bound EPS-carbohydrate seemed to be stimulated during ammonium limitation (Table 2). This have been already mentioned by Orvain (2003) and De Brouwer and Stal (2002). In dense biofilm, the conditions are far from favorable because of a number of environmental stresses, including high $\mathrm{pH}$, low nutrient concentration, and generally slower diffusion rates (de Jong et al., 1988; Decho, 1990). Such stresses lead to a decrease in benthic microalgal production but may cause the release of a greater concentration of exudates (Yallop et al., 2000).

EPS and chlorophyll $a$ concentration had a significant effect on all the bacterial variables (Table 3). The biomass of bacteria decreased during low tide during the second phase of the experiment (Table 2). The aminopeptidase activity increased, more specifically, at low tides (Figure 3, Table 1). The aminopeptidase and $\alpha$-glucosidase activities seemed to have the same trends throughout the experiment. Bacterial enzymatic activities were highly stimulated and thus productive. As the biofilm matures and algae within the biofilm approach the stationary phase, a greater supply of algae exudates was suitable for bacterial utilization and thus bacterial enzymes. Bacteria may be utilizing substrates from the senescing diatoms biofilm, an observation supported by other studies on estuarine mudflats (Wellsbury et al., 1996; Yallop et al., 2000). The EPS-protein seems to become favorable to bacteria during the phase of degradation of the biofilm. On the other hand, bound EPS-carbohydrate fraction had still a negative impact on bacterial production (Table 3). Concerning the bacterial structure during the biofilm degradation, D5-D7 samples clustered in two distinct groups, including the D5 and D6 samples (similarity level $<80 \%$ ) and the D7 samples respectively (similarity level < 85\%) (Fig. 5B). The maturation and then the degradation of the biofilm allow a lower richness than the first period (Table 1).This community shift in term of structure and richness during the second period of the mesocom can be attributed to changes in MPB parameters particularly, the EPS composition and concentration. Additional molecular analysis such as sequencing or Q-PCR need to be performed in order to conclude if the community shift was 
due to total bacterial community response or rather to an decrease of specific bacteria taxa as suggested by Haynes et al. (2007).

\section{Conclusion}

The use of a tidal mesocosm has allowed us to reproduce the summer conditions for the MPB biofilm with the exclusion of predation and weather variations by avoiding resuspension. This tool is well appropriate to highlight the inherent dynamics of the MPB biofilm and the interaction with bacterial community, enzymatic activities and production rates. Similar to all others experimental approaches, the analysis of mesocosms has limitations, with scaling problems often identified as the most important (Carpenter, 1996). However, such enclosures enable controlled, manipulative experiments for the study of community-level processes that would be otherwise difficult or impossible to investigate in the laboratory or in situ (Grice and Reeve, 1982; Huston, 1999). Our study has followed the full development of a biofilm whose different stages can be observed in the field as a result of environmental conditions and the age of the biofilm.

Our experiment had emphasized the influence of the environmental conditions (light, immersion/emersion) on the interactions within the biofilm and also on the effects on biofilm ageing. The bacterial production was inhibited by the bound EPS-carbohydrates especially during the low tide. Bound EPS-carbohydrates nevertheless had no effect on bacterial biomass, suggesting that these EPS has an inhibitory effect on bacterial production and activities but not on bacterial cells division. This observation was also suggested by comparing the EPS and bacterial dynamics on the field, Orvain et al. (This Issue) have suggested that the bound EPS (carbohydrate fraction) secretion have negative effects on bacterial variables and that EPS-protein explains the synergistic effect between benthic diatoms and bacteria in summer. The concentration and composition of EPS therefore has a major role in the bacterial/MPB interactions: these interactions can be either positive or negative in order to regulate the productive phases of MPB and prokaryotes. Experimental studies need to be done with bacterial and diatom cultures in order to decipher the potential antibacterial effects of EPS-compounds. The composition variability (e.g., low and high molecular weight concentrations) of EPS needs also to be studied as bacteria showing fraction-specific preferences (Amon and Benner, 1996; Giroldo et al., 2003).

\section{Acknowledgements}


This work was supported by the French ANR (National Research Agency) through the VASIREMI Project "Trophic significance of microbial biofilms in tidal flats" (Contract ANR06-BLAN-0393-01). This study was supported by the Région Poitou-Charentes for the financial support of the $\mathrm{PhD}$ of $\mathrm{M}$. De Crignis. The authors are grateful to the scientific community of VASIREMI with special thanks to Martine Bréret and Brenda Waqueteux for their support during this study. We are grateful to Dany Prevostat (Aeroglisseurs Services) for technical support during the field experiment. 
Amin, S.A., Parker, M.S., Armbrust, E.V., 2012. Interactions between Diatoms and Bacteria. Microbiology and Molecular Biology Reviews 76, 667-684.

Amon, R.M.W., Benner, R., 1996. Bacterial utilization of different size classes of dissolved organic matter. Limnology and Oceanography 41, 41-51.

Bellinger, B.J., Underwood, G.J.C., Ziegler, S.E., Gretz, M.R., 2009. Significance of diatomderived polymers in carbon flow dynamics within estuarine biofilms determined through isotopic enrichment. Aquatic Microbial Ecology 55, 169-187.

Bhaskar, P.V., Grossart, H.-P., Bhosle, N.B., Simon, M., 2005. Production of macroaggregates from dissolved exopolymeric substances (EPS) of bacterial and diatom origin. FEMS Microbiology Ecology 53, 255-264.

Blanchard, G.F., Guarini, J.M., Orvain, F., Sauriau, P.G., 2001. Dynamic behaviour of benthic microalgal biomass in intertidal mudflats. Journal of Experimental Marine Biology and Ecology 264, 85-100.

Boetius, A., Lochte, K., 1994. Regulation of microbial enzymatic degradation of organic matter in deep-sea sediments. Marine Ecology Progress Series 104, 299-307.

Boetius, A., Lochte, K., 1996. Effect of organic enrichments on hydrolytic potentials and growth of bacteria in deep-sea sediments. Marine Ecology Progress Series 140, 239-250.

Bratbak, G., Dundas, I., 1984. Bacterial dry matter content and biomass estimations. Applied and Environmental Microbiology 48, 755-757.

Cammen, L.M., 1991. Annual bacterial production in relation to benthic microalgal production and sediment oxygen uptake in an intertidal sandflat and an intertidal mudflat Marine Ecology Progress Series 71, 13-25.

Carpenter, S.R., 1996. Microcosm experiments have limited relevance for community and ecosystem ecology. Ecology 77, 677-680.

Chin, W.-C., Orellana, M.V., Verdugo, P., 1998. Spontaneous assembly of marine dissolved organic matter into polymer gels. Nature 391, 568-572.

Chiovitti, A., Higgins, M.J., Harper, R.E., Wetherbee, R., Bacic, A., 2003. The complex polysaccharides of the raphid diatom Pinnularia viridis (Bacillariophyceae). Journal of Phycology 39, 543-554.

Chróst, R.J., Overbeck, J., 1990. Substrate-ectoenzyme interaction: significance of betaglucosidase activity for glucose metabolism by aquatic bacteria. Archiv fuer Hydrobiologie Advances in Limnology 34, 93-98.

Consalvey, M., Paterson, D.M., Underwood, G.J.C., 2004. The ups and downs of life in a benthic biofilm: Migration of benthic diatoms. Diatom Research 19, 181-202.

Cook, P.L.M., Veuger, B., Böer, S., Middelburg, J.J., 2007. Effect of nutrient availability on carbon and nitrogen incorporation and flows through benthic algae and bacteria in near-shore sandy sediment. Aquatic Microbial Ecology 49, 165-180.

de Brouwer, J.F.C., Stal, L.J., 2001. Short-term dynamics in microphytobenthos distribution and associated extracellular carbohydrates in surface sediments of an intertidal mudflat. Marine Ecology Progress Series 218, 33-44.

De Brouwer, J.F.C., Stal, L.J., 2002. Daily fluctuations of exopolymers in cultures of the benthic diatoms Cylindrotheca closterium and Nitzschia sp. (Bacillariophyceae). Journal of Phycology 38, 464-472.

de Jong, S., Hofmann, P., A., S., 1988. Construction and calibration of a rapidly responding pH mini-electrode : application to intertidal sediments. Marine Ecology Progress Series 45, 187-192.

Decho, A.W., 1990. Microbial exopolymer secretions in ocean environments: their role(s) in food webs and marine processes. Oceanography and Marine Biology Annual Review 28, 73153. 
Decho, A.W., 2000. Microbial biofilms in intertidal systems: An overview. Continental Shelf Research 20, 1257-1273.

Dubois, M., Gilles, K.A., Hamilton, J.K., Rebers, P.A., Smith, F., 1956. Colorimetric method for determination of sugars and related substances. Analytical Chemistry 28, 350-356.

Fuhrman, J.A., 1981. Influence of Method on the Apparent Size Distribution of Bacterioplankton Cells: Epifluorescence Microscopy Compared to Scanning Electron Microscopy Marine Ecology Progress Series 5, 103-106.

Fuhrman, J.A., Azam, F., 1982. Thymidine incorporation as a measure of heterotrophic bacterioplankton production in marine surface waters: Evaluation and field results. Marine Biology 66, 109-120.

Gerbersdorf, S., Westrich, B., Paterson, D., 2009. Microbial Extracellular Polymeric Substances (EPS) in Fresh Water Sediments. Microbial Ecology 58, 334-349.

Giroldo, D., Vieira, A.A.H., Paulsen, B.S., 2003. Relative increase of deoxy sugars during microbial degradation of an extracellular polysaccharide released by a tropical freswater Thalassiosira sp. (Bacillariophyceae). Journal of Phycology 39, 1109-1115.

Gonzales, T., Robert-Baudouy, J., 1996. Bacterial aminopeptidases: Properties and functions. FEMS Microbiology Reviews 18, 319-344.

Goto, N., Mitamura, O., Terai, H., 2001. Biodegradation of photosynthetically produced extracellular organic carbon from intertidal benthic algae. Journal of Experimental Marine Biology and Ecology 257, 73-86.

Grice, G.D., Reeve, M.R., 1982. Marine Mesocosms: Biological and Chemical Research in Experimental Ecosystems, New York.

Guarini, J.-M., Blanchard, G.F., Gros, P., Gouleau, D., Bacher, C., 2000. Dynamic model of the short-term variability of microphytobenthic biomass on temperate intertidal mudflats. Marine Ecology Progress Series 195, 291-303.

Hamels, I., Muylaert, K., Casteleyn, G., Vyverman, W., 2001. Uncoupling of bacterial production and flagellate grazing in aquatic sediments: a case study from an intertidal flat. Aquatic Microbial Ecology 25, 31-42.

Hanlon, A.R.M., Bellinger, B., Haynes, K., Xiao, G., Hofmann, T.A., Gretz, M.R., Ball, A.S., Osborn, A.M., Underwood, G.J.C., 2006. Dynamics of extracellular polymeric substance (EPS) production and loss in an estuarine, diatom-dominated, microalgal biofilm over a tidal emersion-immersion period. Limnology and Oceanography 51, 79-93.

Haynes, K., Hofmann, T.A., Smith, C.J., Ball, A.S., Underwood, G.J.C., Osborn, A.M., 2007. Diatom-derived carbohydrates as factors affecting bacterial community composition in estuarine sediments. Applied and Environmental Microbiology 73, 6112-6124.

Herlory, O., Guarini, J.-M., Richard, P., Blanchard, G.F., 2004. Microstructure of microphytobenthic biofilm and its spatio-temporal dynamics in an intertidal mudflat (Aiguillon Bay, France). Marine Ecology Progress Series 282, 33-44.

Heuer, H., Smalla, K., 1997. Application of denaturing gradient gel electrophoresis and temperature gradient gel electrophoresis for studying soil microbial communities, in: van Elsas, J.D. (Ed.), Modern Soil Microbiology. Marcel Dekker, New York, pp. 353-373.

Higgins, M.J., Molino, P., Mulvaney, P., Wetherbee, R., 2003. The structure and nanomechanical properties of the adhesive mucilage that mediates diatom-substratum adhesion and motility. Journal of Phycology 39, 1181-1193.

Hoppe, H.-G., 1984. Attachment of bacteria: advantage or disadvantage for survival in the aquatic environment, in: Marshall, K.C. (Ed.), Microbial adhesion and aggregation. SpringerVerlag, Berlin, pp. 283-301.

Huston, M.A., 1999. Microcosm experiments have limited relevance for community and ecosystem ecology: Synthesis of comments Ecology 80, 1088-1089. 
Kemp, W.M., Petersen, J.E., Gardner, R.H., 2001. Scale-dependence and the problem of extrapolation: Implications for experimental and natural coastal ecosystems, in: Gardner, R.H., Kemp, W.M., Kennedy, V.S., Petersen, J.E. (Eds.), Scaling Relations in Experimental Ecology. University Press, New York, Columbia pp. 3-57.

King, G.M., 1986. Characterization of $\beta$-Glucosidase Activity in Intertidal Marine Sediments. Applied and Environmental Microbiology 51, 373-380.

Koroleff, F., 1969. Direct determination of ammonia in natural waters as indophenol blue. International Council for the Exploration of the Sea 9, 19-22.

Lorenzen, C.J., 1966. A method for the continuous measurement of in vivo chlorophyll concentration. Deep-Sea Research and Oceanographic Abstracts 13, 223-227.

Lowry, O.H., Rosenbrough, N.J., Farr, A.L., Randall, R.J., 1951. Protein measurement with the Folin Phenol Reagent. Journal of Biological Chemistry 193, 265-275.

Lubarsky, H.V., Hubas, C., Chocholek, M., Larson, F., Manz, W., Paterson, D.M., Gerbersdorf, S.U., 2010. The Stabilisation Potential of Individual and Mixed Assemblages of Natural Bacteria and Microalgae. PLoS ONE 5, e13794.

MacIntyre, H., Geider, R., Miller, D., 1996. Microphytobenthos: the ecological role of the "secret garden" of unvegetated shallow-water marine habitats. I. Distribution, abundance and primary production. Estuaries 19, 186-201.

Makk, J., Acs, E., Marialigeti, K., Kovacs, G., 2003. Investigations on the Danube gravelbiofilm diatom-associated bacterial communities. Biologia 58, 729-742.

Mallet, C., Debroas, D., 1999. Relations between organic matter and bacterial proteolytic activity in sediment surface layers of a eutrophic lake (Lake Aydat, Puy de Dome, France). Archiv fuer Hydrobiologie 145, 39-56.

Mallet, C., Debroas, D., 2001. Regulation of $\beta$ - and $\alpha$-glycolytic activities in the sediments of a eutrophic lake. Microbial Ecology 41, 106-113.

Middelburg, J.J., Barranguet, C., Boschker, H.T.S., Herman, P.M.J., Moens, T., Heip, C.H.R., 2000. The fate of intertidal microphytobenthos carbon: An in situ 13C-labeling study. Limnology and Oceanography 45, 1224-1234.

Orvain, F., De Crignis, M., Guizien, K., Lefebvre, S., Mallet, C., Takahashi, E., Dupuy, C., This Issue. Tidal and seasonal effects on the consortium of bacteria, microphytobanthos and exopolymers in natural intertidal biofilms (Brouage, France).

Orvain, F., Galois, R., Barnard, C., Sylvestre, A., Blanchard, G., Sauriau, P.G., 2003. Carbohydrate production in relation to microphytobenthic biofilm development: An integrated approach in a tidal mesocosm. Microbial Ecology 45, 237-251.

Pascal, P.-Y., Dupuy, C., Richard, P., Mallet, C., Châtelet, E.A.d., Niquil, N., 2009. Seasonal variation in consumption of benthic bacteria by meio- and macrofauna in an intertidal mudflat. Limnology and Oceanography 54, 1048-1059.

Pesce, S., Fajon, C., Bardot, C., Bonnemoy, F., Portelli, C., Bohatier, J., 2006. Effects of the phenylurea herbicide diuron on natural riverine microbial communities in an experimental study. Aquatic Toxicology 78, 303-314.

Petersen, J.E., Kemp, W.M., Bartleson, R., Boynton, W.R., Chen, C.C., Cornwell, J.C., Gardner, R.H., Hinkle, D.C., Houde, E.D., Malone, T.C., Mowitt, W.R., Murray, L., Sanford, L.P., Stevenson, J.C., Sundberg, K.L., Suttles, S.E., 2003. Multiscale Experiments in Coastal Ecology: Improving Realism and Advancing Theory. BioScience 53, 1181-1197.

Pierre, G., Graber, M., Orvain, F., Dupuy, C., Maugard, T., 2010. Biochemical characterization of extracellular polymeric substances extracted from an intertidal mudflat using a cation exchange resin. Biochemical Systematics and Ecology 38, 917-923.

Pierre, G., Graber, M., Rafiliposon, B., Dupuy, C., Orvain, F., Crignis, M., Maugard, T., 2012. Biochemical Composition and Changes of Extracellular Polysaccharides (ECPS) 
Produced during Microphytobenthic Biofilm Development (Marennes-Oléron, France). Microbial Ecology 63, 157-169.

Porter, K.G., Feig, Y.S., 1980. The use of DAPI for identifying and counting aquatic microflora. Limnology and Oceanography 25, 943-948.

Potts, M., 1994. Desiccation tolerance of prokaryotes. Microbiology and Molecular Biology Reviews 58, 755-805.

Smith, D.C., Simon, M., Alldredge, A.L., Azam, F., 1992. Intense hydrolytic enzyme activity on marine aggregates and implications for rapid particle dissolution. Nature 359, 139-142.

Smith, D.J., Underwood, G.J.C., 1998. Exopolymer production by intertidal epipelic diatoms. Limnology and Oceanography 43, 1578-1591.

Smith, D.J., Underwood, G.J.C., 2000. The production of extracellular carbohydrates by estuarine benthic diatoms: the effects of growth phase and light and dark treatment. Journal of Phycology 36, 321-333.

Staats, N., Stal, L.J., De Winder, B., Mur, L.R., 2000a. Oxygenic photosynthesis as driving process in exopolysaccharide production of benthic diatoms. Marine Ecology Progress Series 193, 261-269.

Staats, N., Stal, L.J., Mur, L.R., 2000b. Exopolysaccharide production by the epipelic diatom Cylindrotheca closterium: Effects of nutrient conditions. Journal of Experimental Marine Biology and Ecology 249, 13-27.

Stal, L., de Brower, J., 2003. Biofilm formation by benthic diatoms and their influence on the stabilization of intertidal mudflats. Forschungszentrum TERRAMARE 12, 109-111.

Stal, L.J., Défarge, C., 2005. Structure and dynamics of exopolymers in an intertidal diatom biofilm. Geomicrobiology Journal 22, 341-352.

Sutherland, I.W., 1999. Polysaccharases for microbial exopolysaccharides. Carbohydrate Polymers 38, 319-328.

Sutherland, T.F., Grant, J., Amos, C.L., 1998. The effect of carbohydrate production by the diatom Nitzschia curvilineata on the erodibility of sediment. Limnology and Oceanography 43, 65-72.

Takahashi, E., Ledauphin, J., Goux, D., Orvain, F., 2009. Optimising extraction of extracellular polymeric substances (EPS) from benthic diatoms: Comparison of the efficiency of six EPS extraction methods. Marine and Freshwater Research 60, 1201-1210.

Thornton, D.C.O., Kopac, S.M., Long, R.A., 2010. Production and enzymatic hydrolysis of carbohydrates in intertidal sediment. Aquatic Microbial Ecology 60, 109-125.

Tréguer, P., Le Corre, P., Grall, J.R., 1979. The seasonal variations of nutrients in the upper waters of the Bay of Biscay region and their relation to phytoplankton growth. Deep Sea Research Part A, Oceanographic Research Papers 26, 1121-1152.

Underwood, G.J.C., Boulcott, M., Raines, C.A., Waldron, K., 2004. Environmental effects on exopolymer production by marine benthic diatoms: dynamics, changes in composition, and pathways of production. Journal of Phycology 40, 293-304.

Underwood, G.J.C., Kromkamp, J.C., 1999. Primary production by phytoplankton and microphytobenthos in estuaries. Advances in Ecological Research 29, 93-153.

Underwood, G.J.C., Paterson, D.M., 2003. The importance of extracellular carbohydrate production by marine epipelic diatoms, in: Callow, J.A. (Ed.), Advances in Botanical Research. Academic Press, pp. 183-240.

Underwood, G.J.C., Paterson, D.M., Parkes, R.J., 1995. The Measurement of Microbial Carbohydrate Exopolymers from Intertidal Sediments. Limnology and Oceanography 40, 1243-1253.

van Duyl, F.C., De Winder, B., Kop, A.J., Wollenzien, U., 1999. Tidal coupling between carbohydrate concentrations and bacterial activities in diatom-inhabited intertidal mudflats. Marine Ecology Progress Series 191, 19-32. 
van Duyl, F.C., Kop, A.J., 1990. Seasonal patterns of bacterial production and biomass in intertidal sediments of the western Dutch Wadden Sea Marine Ecology Progress Series 59, 249-261.

Waksman, S.A., Butler, M.R., 1937. Relation of Bacteria to Diatoms in sea water. Journal of the Marine Biological Association of the United Kingdom 22, 359-373.

Ward, J.H., 1963. Hierarchical grouping to optimize an objective function. Journal of the American Statistical Association 58, 236-244.

Weerman, E.J., van de Koppel, J., Eppinga, M.B., Montserrat, F., Liu, Q.-X., Herman, P.M.J., 2010. Spatial Self-Organization on Intertidal Mudflats through Biophysical Stress Divergence. The American Naturalist 176, 15-32.

Wellsbury, P., Herbert, R.A., Parkes, J.R., 1996. Bacterial activity and production in nearsurface estuarine and freshwater sediments. FEMS Microbiology Ecology 19, 203-214.

Wustman, B.A., Gretz, M.R., Hoagland, K.D., 1997. Extracellular matrix assembly in diatoms (Bacillariophyceae): I. A model of adhesives based on chemical characterization and localization of polysaccharides from the marine diatom Achnanthes longipes and other diatoms. Plant Physiology 113, 1059-1069.

Yallop, M.L., deWinder, B., Paterson, D.M., Stal, L.J., 1994. Comparative structure, primary production and biogenic stabilization of cohesive and non cohesive marine sediments inhabited by microphytobenthos. Estuarine, Coastal and Shelf Science 39, 565-582.

Yallop, M.L., Paterson, D.M., Wellsbury, P., 2000. Interrelationships between rates of microbial production, exopolymer production, microbial biomass, and sediment stability in biofilms of intertidal sediments. Microbial Ecology 39, 116-127. 
Legend :

Table 1: Mean and Standard Deviation (SD) for each variable and results of the Student test. Values of variables of the low tide were tested against values of variables of the high tide for (a) D1-D4 period $(n=7)$ and for (b) the D5-D8 period $(n=8)$. On average significant difference: $* * \mathrm{p}<0.01, * \mathrm{p}<0.05$ levels, ns: not significant

Table 2: Mean diff. and Standard Deviation diff. (SD diff.) for each variable and results of the Student test (diff. : Values of the end of the low tide minus values of the beginning of the low tide). Mean diff. were positive when values increased over the low tide.

Student test: Low tide values of variables of D1-D4 period were tested against low tide values of D5-D8 $(\mathrm{n}=3)$. On average, the significant difference was: ${ }^{*} \mathrm{p}<0.01,{ }^{*} \mathrm{p}<0.05$ levels, $\mathrm{ns}$ : not significant

Table 3:

Pearson's correlation matrix between bacterial variables and environmental parameters. The correlation coefficients are given when $p \leq 0.05$. Bacterial variables are bacterial biomass (BB), bacterial production (BP), $\alpha$-glucosidase activity ( $\alpha$-gluco), $\beta$-glucosidase activity ( $\beta-$ gluco), aminopeptidase activity (aminoP) and, bacterial richness (BR). Environmental parameters are chlorophyll $a(\mathrm{Chl} a$ ), colloidal carbohydrates (coll C), bound carbohydrates (bound $\mathrm{C}$ ), colloidal proteins (coll P), bound proteins (bound $\mathrm{P}$ ), phosphate concentration $\left(\mathrm{PO}_{4}\right)$ and ammonium concentration $\left(\mathrm{NH}_{4}\right)$.

Significance was tested by a F-test with 2 degrees (* : $\mathrm{P} \leq 0.05$ and $* *: \mathrm{P} \leq 0.01$ ).

Figure 1: Temporal dynamics of abiotic parameters during the experiment, a. temperature, salinity and light intensity; b. nutrients and pore water content. The gray bars indicate the low tides during the experiment.

Figure 2: Temporal dynamics of chlorophyll $a$, bacterial biomass and bacterial production. The gray bars indicate the low tides during the experiment.

Figure 3: Temporal dynamics of a. the different fractions of EPS $b$. the ratio of different fractions of EPS to chlorophyll $a$ concentrations. The gray bars indicate the low tides during the experiment.

Figure 4: Temporal dynamics of bacterial enzymatic activities. The gray bars indicate the low tides during the experiment.

Figure 5: Dendrogram (unweighted pair group method with arithmetic averages UPGMA) generated from DGGE profiles representing similarities in branching patterns between samples. The cluster analysis of all the samples highlighted that there was a strong shift in bacterial structure during the day 4 (data not shown). Therefore another cluster analysis was applied with samples of each phase: D1-D4 period (A.) and D5-D7 period (B.). Each sample is named according to the day of the experiment (from D1 to D7), the time of the sampling, and the tide (LT:low tide; HT: high tide). The similarity percentage between each sample is indicated at each node (Dice). 
Table 1: Mean and Standard Deviation (SD) for each variable and results of the Student test. Values of variables of the low tide were tested against values of variables of the high tide for (a) D1-D4 period $(n=7)$ and for (b) the D5-D8 period $(n=8)$. On average significant difference: $* * \mathrm{p}<0.01, * \mathrm{p}<0.05$ levels, ns: not significant

\begin{tabular}{rrrrrc}
\hline & \multicolumn{2}{c}{ Low Tide } & \multicolumn{2}{c}{ High Tide } & Student test \\
& Mean & SD & Mean & SD & p \\
\hline (a) D1-D4 period & & & & & \\
\hline bacteria $\left(\mathrm{mgC} / \mathrm{m}^{2}\right)$ & 262.1 & 58.9 & 253.6 & 56.4 & $\mathrm{~ns}$ \\
bacterial production $\left(\mathrm{mgC} / \mathrm{m}^{2} / \mathrm{d}\right)$ & 156.3 & 30.0 & 183.6 & 30.8 & $*$ \\
chlorophyll $a\left(\mathrm{mg} / \mathrm{m}^{2}\right)$ & 103.3 & 17.8 & 107.0 & 18.8 & $\mathrm{~ns}$ \\
$\alpha$-glucosidase $\left(\mathrm{mM} / \mathrm{d} / \mathrm{m}^{2}\right)$ & 208.5 & 72.7 & 242.3 & 104.4 & $\mathrm{~ns}$ \\
$\beta$-glucosidase $\left(\mathrm{mM} / \mathrm{d} / \mathrm{m}^{2}\right)$ & 470.6 & 196.8 & 485.7 & 192.4 & $\mathrm{~ns}$ \\
aminopeptidase $\left(\mathrm{M} / \mathrm{d} / \mathrm{m}^{2}\right)$ & 4.2 & 2.3 & 4.3 & 2.4 & $\mathrm{~ns}$ \\
colloidal carbohydrates $\left(\mathrm{mg} / \mathrm{m}^{2}\right)$ & 112.8 & 26.1 & 108.9 & 25.6 & $\mathrm{~ns}$ \\
bound carbohydrates $\left(\mathrm{mg} / \mathrm{m}^{2}\right)$ & 270.5 & 43.5 & 219.2 & 32.0 & $\mathrm{~ns}$ \\
colloidal protein $\left(\mathrm{mg} / \mathrm{m}^{2}\right)$ & 376.5 & 66.5 & 419.6 & 73.7 & $\mathrm{~ns}$ \\
bound protein $\left(\mathrm{mg} / \mathrm{m}^{2}\right)$ & 411.5 & 67.2 & 413.6 & 40.9 & $\mathrm{~ns}$ \\
bacterial $\mathrm{richmess}$ & 14.1 & 3.3 & 15.9 & 2.2 & $\mathrm{~ns}$ \\
\hline b) D5-D8 period & & & & & \\
\hline bacteria $\left(\mathrm{mgC} / \mathrm{m}^{2}\right)$ & 263.1 & 65.0 & 216.0 & 33.0 & $\mathrm{~ns}$ \\
bacterial production $\left(\mathrm{mgC} / \mathrm{m}^{2} / \mathrm{d}\right)$ & 130.0 & 38.9 & 130.6 & 57.0 & $\mathrm{~ns}$ \\
chlorophyll $a\left(\mathrm{mg} / \mathrm{m}^{2}\right)$ & 116.4 & 11.7 & 111.4 & 10.1 & $* *$ \\
$\alpha$-glucosidase $\left(\mathrm{mM} / \mathrm{d} / \mathrm{m}^{2}\right)$ & 246.1 & 103.6 & 236.1 & 27.3 & $\mathrm{~ns}$ \\
$\beta$-glucosidase $\left(\mathrm{mM} / \mathrm{d} / \mathrm{m}^{2}\right)$ & 451.2 & 193.2 & 459.3 & 101.9 & $\mathrm{~ns}$ \\
aminopeptidase $\left(\mathrm{M} / \mathrm{d} / \mathrm{m}^{2}\right)$ & 6.6 & 3.1 & 5.3 & 2.7 & $\mathrm{~ns}$ \\
colloidal carbohydrates $\left(\mathrm{mg} / \mathrm{m}^{2}\right)$ & 94.7 & 9.2 & 91.4 & 43.2 & $\mathrm{~ns}$ \\
bound carbohydrates $\left(\mathrm{mg} / \mathrm{m}^{2}\right)$ & 270.3 & 40.2 & 281.2 & 75.4 & $\mathrm{~ns}$ \\
colloidal protein $\left(\mathrm{mg} / \mathrm{m}^{2}\right)$ & 341.2 & 177.2 & 284.8 & 154.4 & $\mathrm{~ns}$ \\
bound protein $\left(\mathrm{mg} / \mathrm{m}^{2}\right)$ & 425.4 & 39.2 & 472.8 & 157.2 & $\mathrm{~ns}$ \\
bacterial $\mathrm{richness}$ & 12.0 & 3.3 & 10.8 & 2.5 & $\mathrm{~ns}$ \\
\hline & & & & &
\end{tabular}


Table 2: Mean diff. and Standard Deviation diff. (SD diff.) for each variable and results of the Student test (diff. : Values of the end of the low tide minus values of the beginning of the low tide). Mean diff. were positive when values increased over the low tide.

Student test : Low tide values of variables of D1-D4 period were tested against low tide values of D5-D8 ( $\mathrm{n}=3)$. On average significant difference: $* * \mathrm{p}<0.01, * \mathrm{p}<0.05$ levels, ns: not significant.

\begin{tabular}{lrrrrc}
\hline & \multicolumn{2}{c}{ D1-D4 period } & \multicolumn{2}{c}{ D5-D8 period } & Student test \\
\cline { 2 - 5 } & Mean diff & SD diff & Mean diff & SD diff & $\mathrm{p}$ \\
\hline Low tide & & & & & \\
bacteria $\left(\mathrm{mgC} / \mathrm{m}^{2}\right)$ & 13.9 & 108.8 & -70.1 & 69.0 & $\mathrm{~ns}$ \\
bacterial production $\left(\mathrm{mgC} / \mathrm{m}^{2} / \mathrm{d}\right)$ & -16.1 & 23.8 & -71.2 & 22.7 & $\mathrm{~ns}$ \\
chlorophyll $a\left(\mathrm{mg} / \mathrm{m}^{2}\right)$ & 22.0 & 21.4 & 17.3 & 14.3 & $\mathrm{~ns}$ \\
$\alpha$-glucosidase $\left(\mathrm{mM} / \mathrm{d} / \mathrm{m}^{2}\right)$ & -18.9 & 42.5 & 72.4 & 148.7 & $\mathrm{~ns}$ \\
$\beta$-glucosidase $\left(\mathrm{mM} / \mathrm{d} / \mathrm{m}^{2}\right)$ & -304.1 & 163.2 & -73.9 & 203.2 & $\mathrm{~ns}$ \\
aminopeptidase $\left(\mathrm{M} / \mathrm{d} / \mathrm{m}^{2}\right)$ & -2.1 & 2.2 & 3.2 & 4.4 & $\mathrm{~ns}$ \\
colloidal carbohydrates $\left(\mathrm{mg} / \mathrm{m}^{2}\right)$ & 38.3 & 7.5 & 6.6 & 14.3 & $\mathrm{~ns}$ \\
bound carbohydrates $\left(\mathrm{mg} / \mathrm{m}^{2}\right)$ & -15.4 & 44.5 & 9.7 & 80.7 & $\mathrm{~ns}$ \\
colloidal protein $\left(\mathrm{mg} / \mathrm{m}^{2}\right)$ & -30.0 & 138.8 & -116.3 & 287.6 & $\mathrm{~ns}$ \\
bound protein $\left(\mathrm{mg} / \mathrm{m}^{2}\right)$ & 20.7 & 40.6 & -79.8 & 15.4 & $*$ \\
Bacterial richness & -0.3 & 2.3 & 0.7 & 5.0 & $\mathrm{~ns}$ \\
\hline
\end{tabular}


Table 3 :

Pearson's correlation matrix between bacterial variables and environmental parameters. The correlation coefficients are given when $p \leq 0.05$. Bacterial variables are bacterial biomass (BB), bacterial production (BP), $\alpha$-glucosidase activity ( $\alpha$-gluco), $\beta$-glucosidase activity ( $\beta-$ gluco), aminopeptidase activity (aminoP) and, bacterial richness (BR). Environmental parameters are chlorophyll $a(\mathrm{Chl} a)$, colloidal carbohydrates (coll C), bound carbohydrates (bound $\mathrm{C}$ ), colloidal proteins (coll $\mathrm{P}$ ), bound proteins (bound $\mathrm{P}$ ), phosphate concentration $\left(\mathrm{PO}_{4}\right)$ and ammonium concentration $\left(\mathrm{NH}_{4}\right)$.

Significance was tested by a F-test with 2 degrees (* : $\mathrm{P} \leq 0.05$ and $* *: \mathrm{P} \leq 0.01$ ).

\begin{tabular}{|c|c|c|c|c|c|c|c|c|c|c|c|c|c|}
\hline & $\mathrm{NH}_{4}$ & $\mathrm{PO}_{4}$ & BB & BP & chl a & $\alpha$-gluco & $\beta$-gluco & aminoP & coll C & bound $\mathrm{C}$ & coll P & bound $\mathrm{P}$ & BR \\
\hline \multicolumn{14}{|l|}{$\mathrm{NH}_{4}$} \\
\hline $\mathrm{PO}_{4}$ & 1 & & & & & & & & & & & & \\
\hline BB & 1 & $0.54^{* *}$ & & & & & & 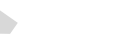 & & & & & \\
\hline BP & $0.54 * *$ & $0.38^{*}$ & 1 & & & & & & & & & & \\
\hline chl a & $-0.39^{* * *}$ & $-0.53 * *$ & 1 & $-0.36^{* *}$ & & & & & & & & & \\
\hline$\alpha$-gluco & 1 & 1 & 1 & 1 & $0.38^{* * *}$ & & & & & & & & \\
\hline$\beta$-gluco & 1 & 1 & 1 & 1 & 1 & I & & & & & & & \\
\hline aminoP & 1 & 1 & 1 & 1 & 1 & $0.48 * *$ & 1 & & & & & & \\
\hline coll C & 1 & 1 & 1 & 1 & 1 & 1 & 7 & 1 & & & & & \\
\hline bound C & $-0.45^{* * *}$ & 1 & 1 & $-0.65 * *$ & $0.41^{* *}$ & 1 & 1 & 1 & 1 & & & & \\
\hline coll P & 1 & 7 & 1 & 1 & I & I & 1 & 7 & 1 & 1 & & & \\
\hline bound P & 1 & 1 & 1 & 1 & 1 & 1 & 1 & 1 & 1 & 1 & I & & \\
\hline BR & 1 & $0.55 * *$ & 1 & 1 & 1 & 1 & 1 & I & 1 & 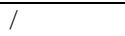 & $0.38^{*}$ & $-0.37 * *$ & \\
\hline
\end{tabular}


a.

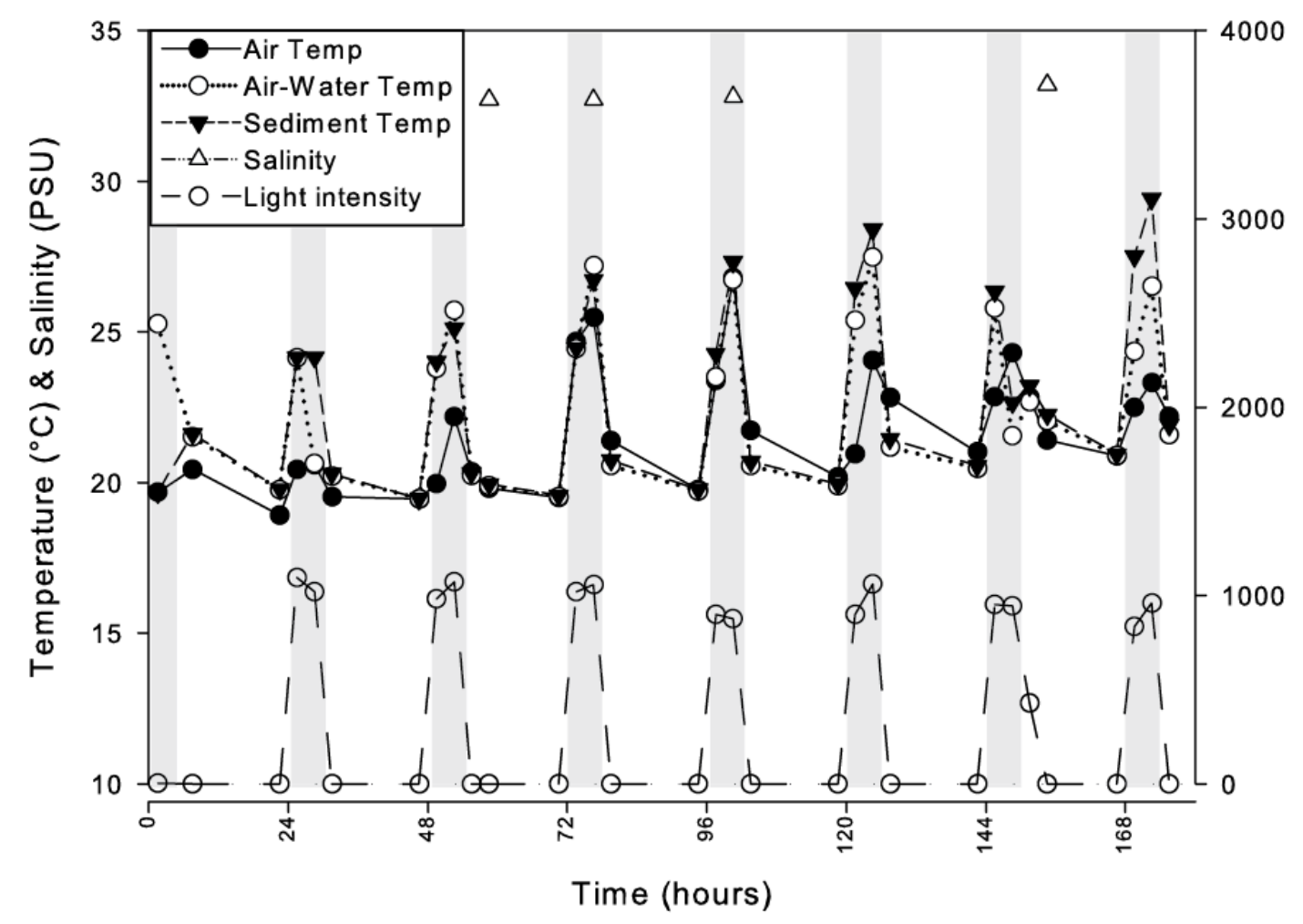

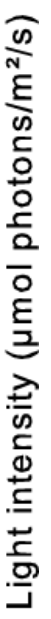

b.

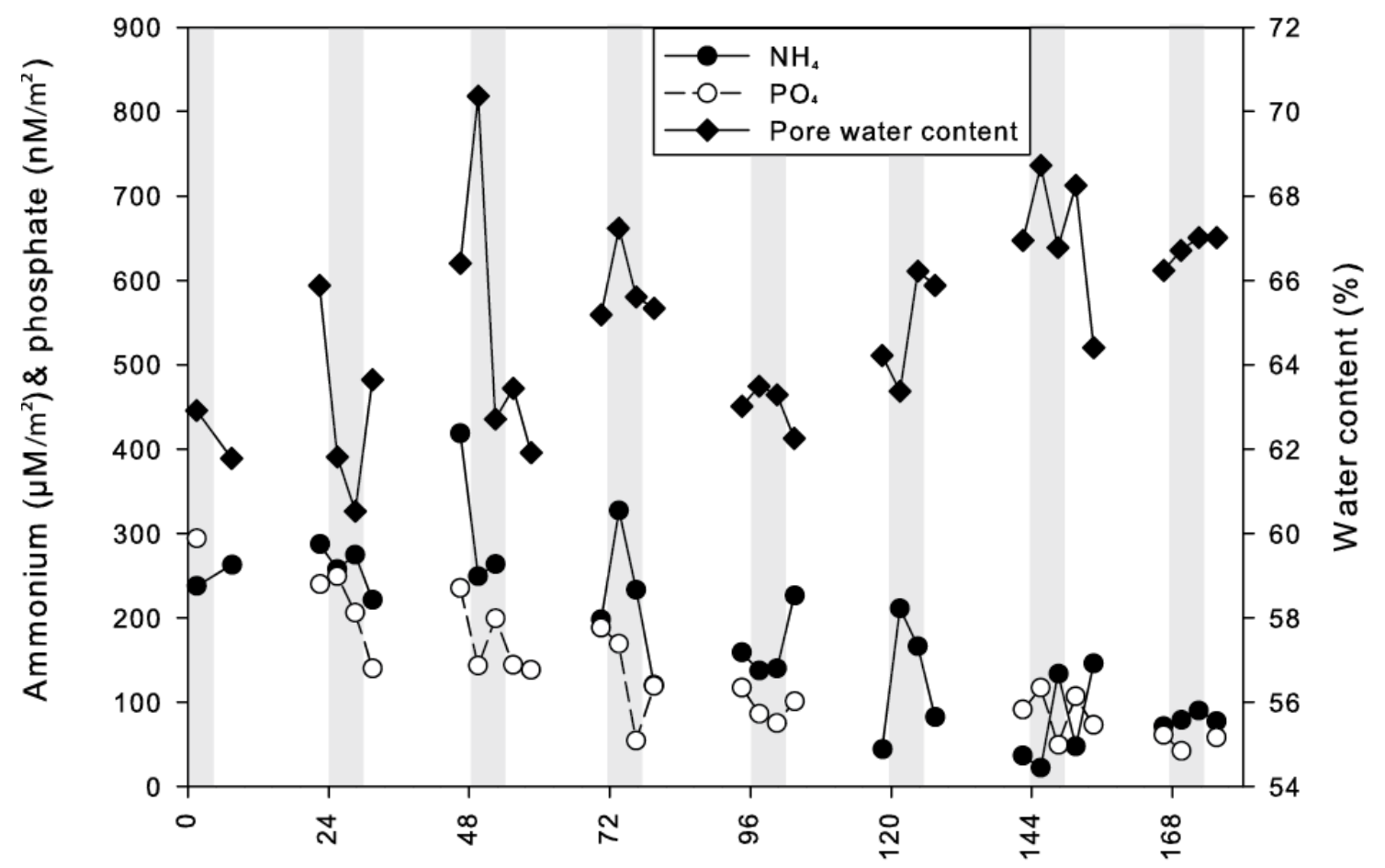

Time (hours)

Figure 1 


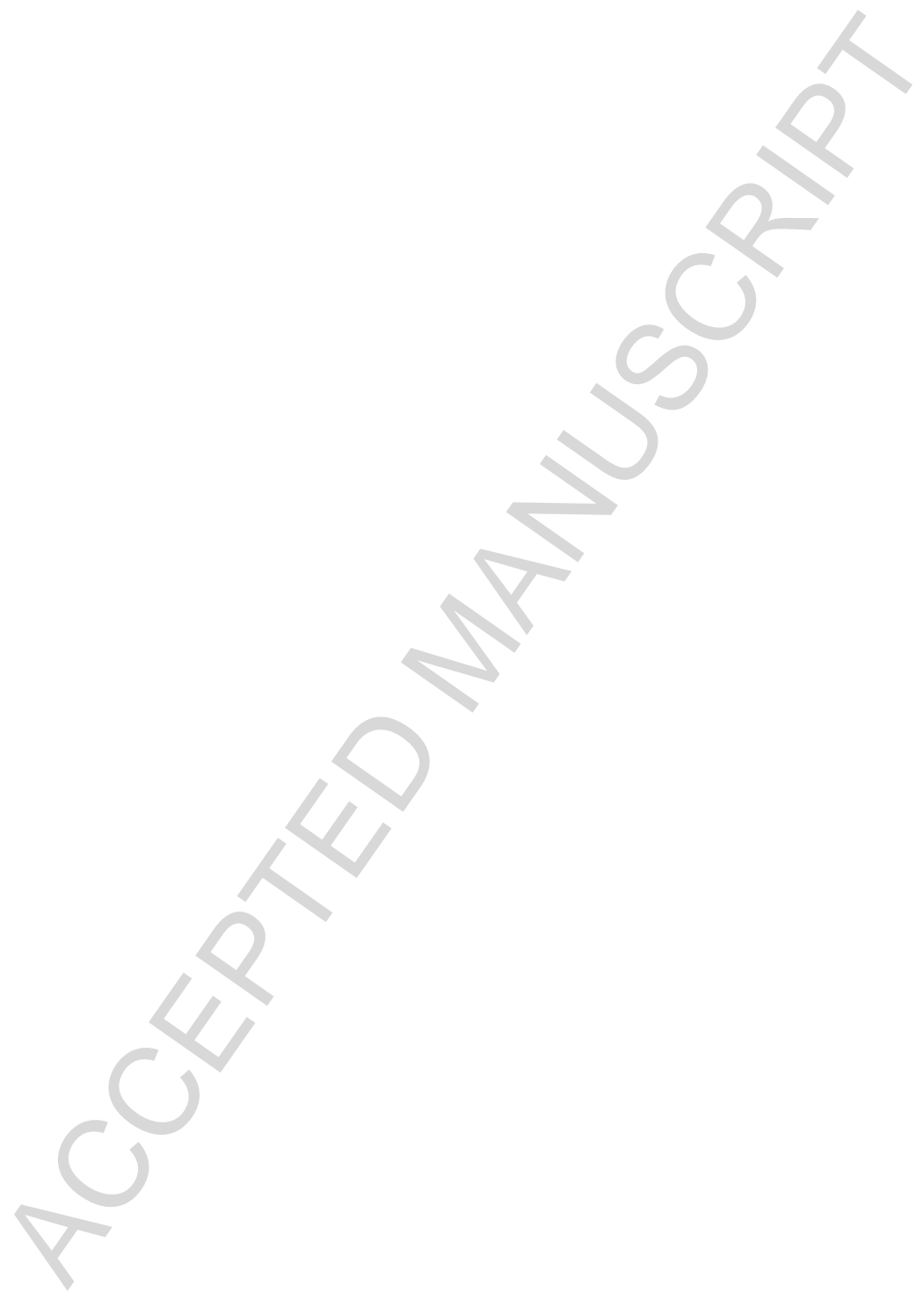




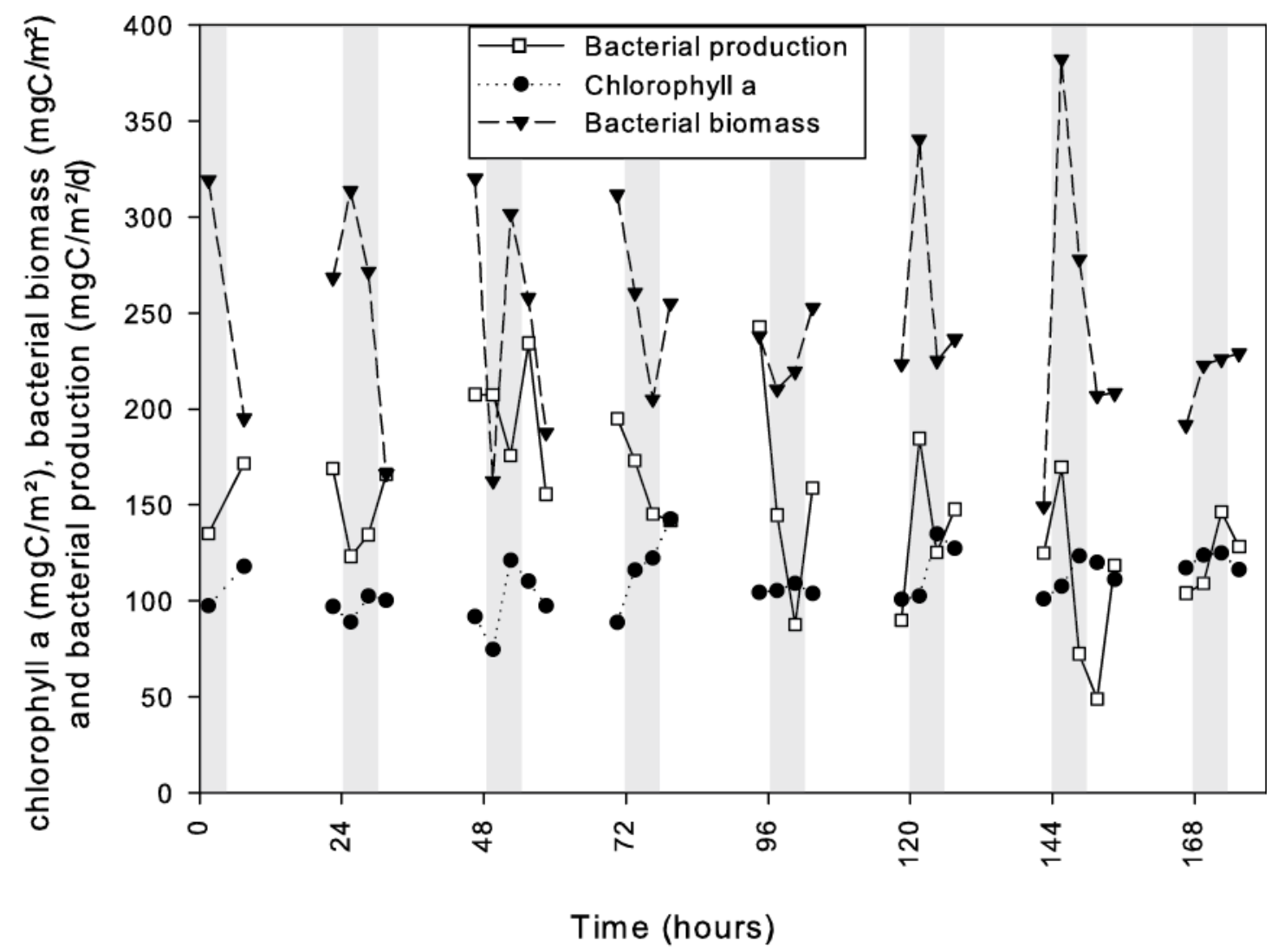

Figure 2 
a.

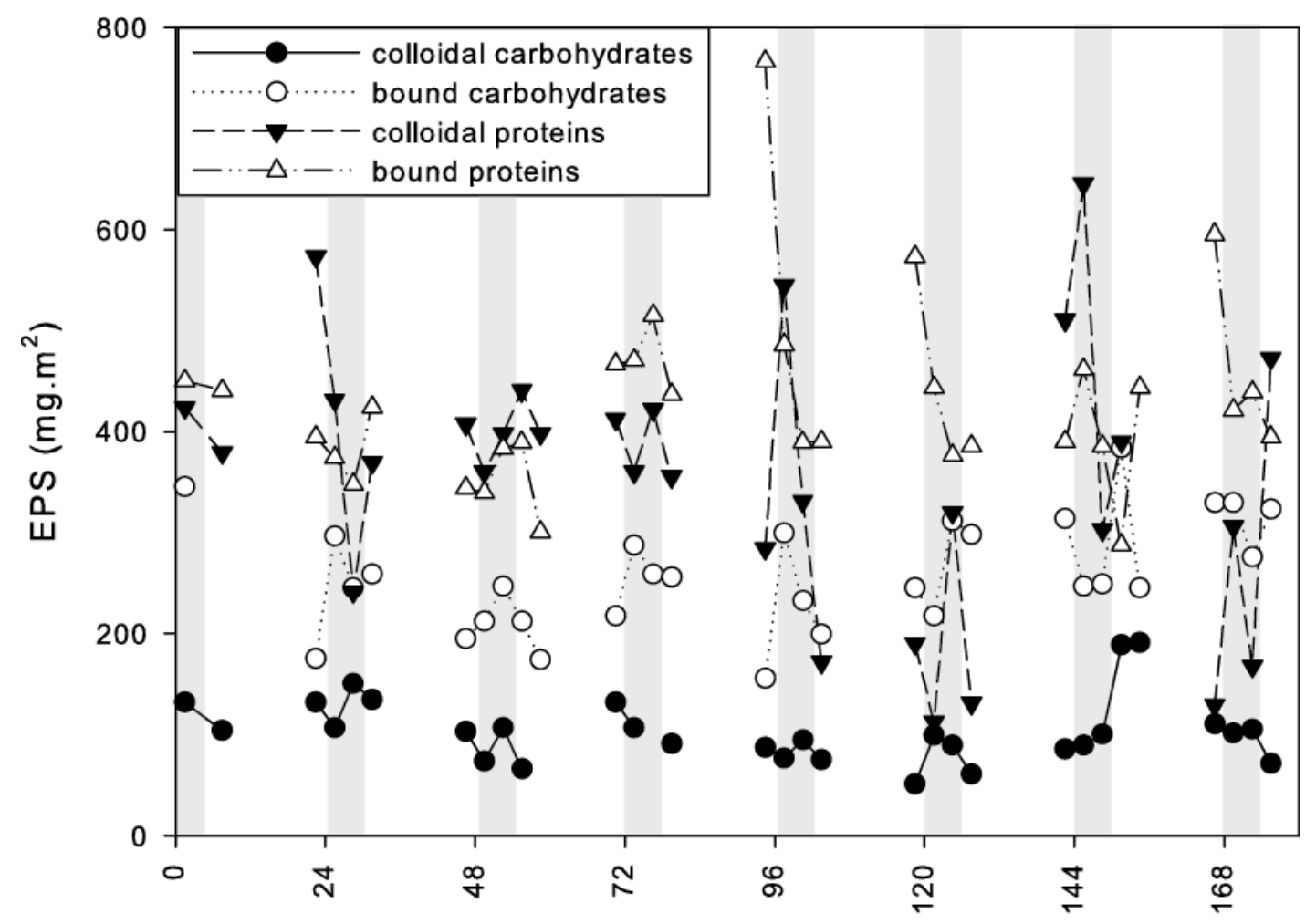

b.

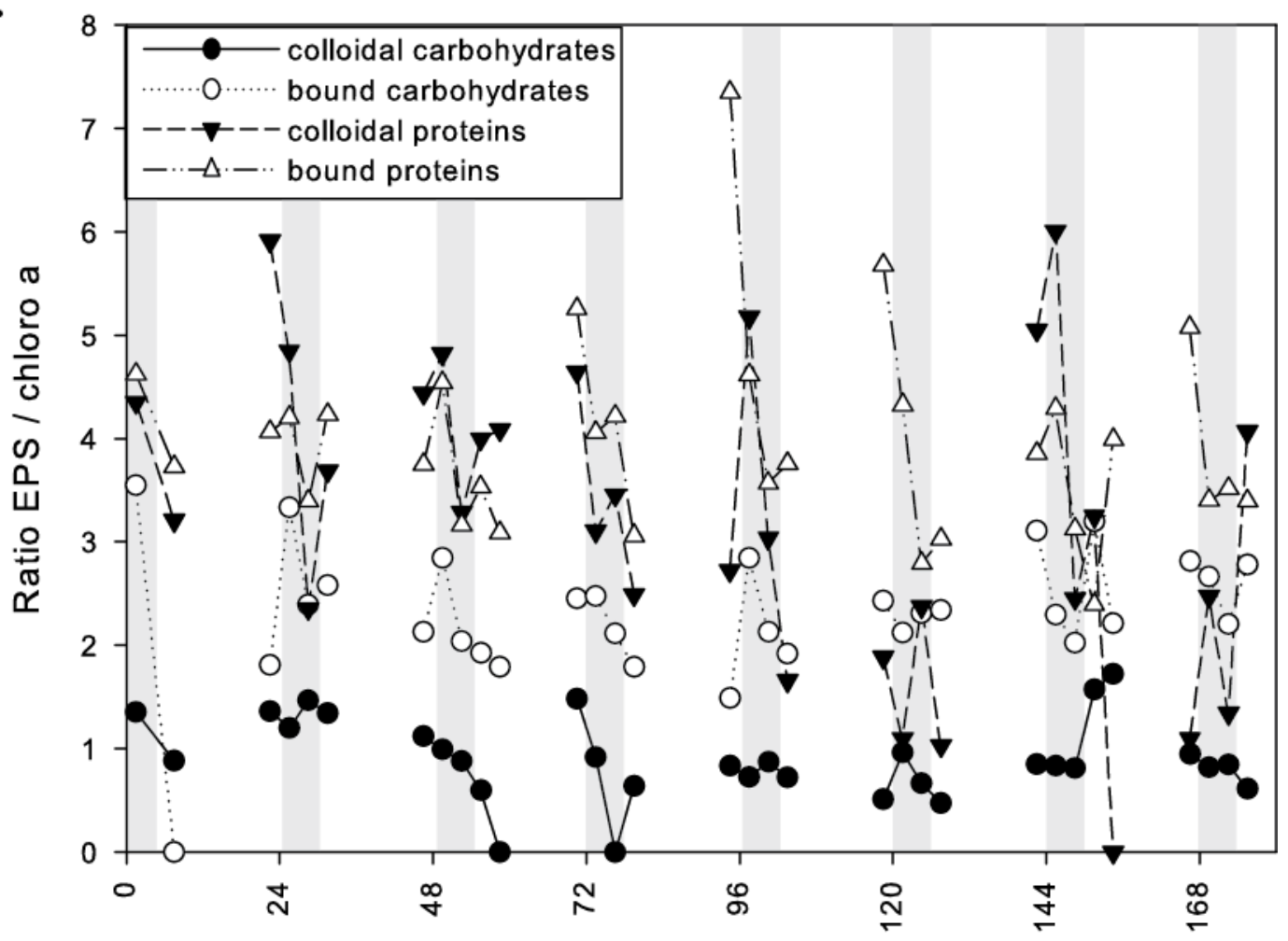

Figure 3 


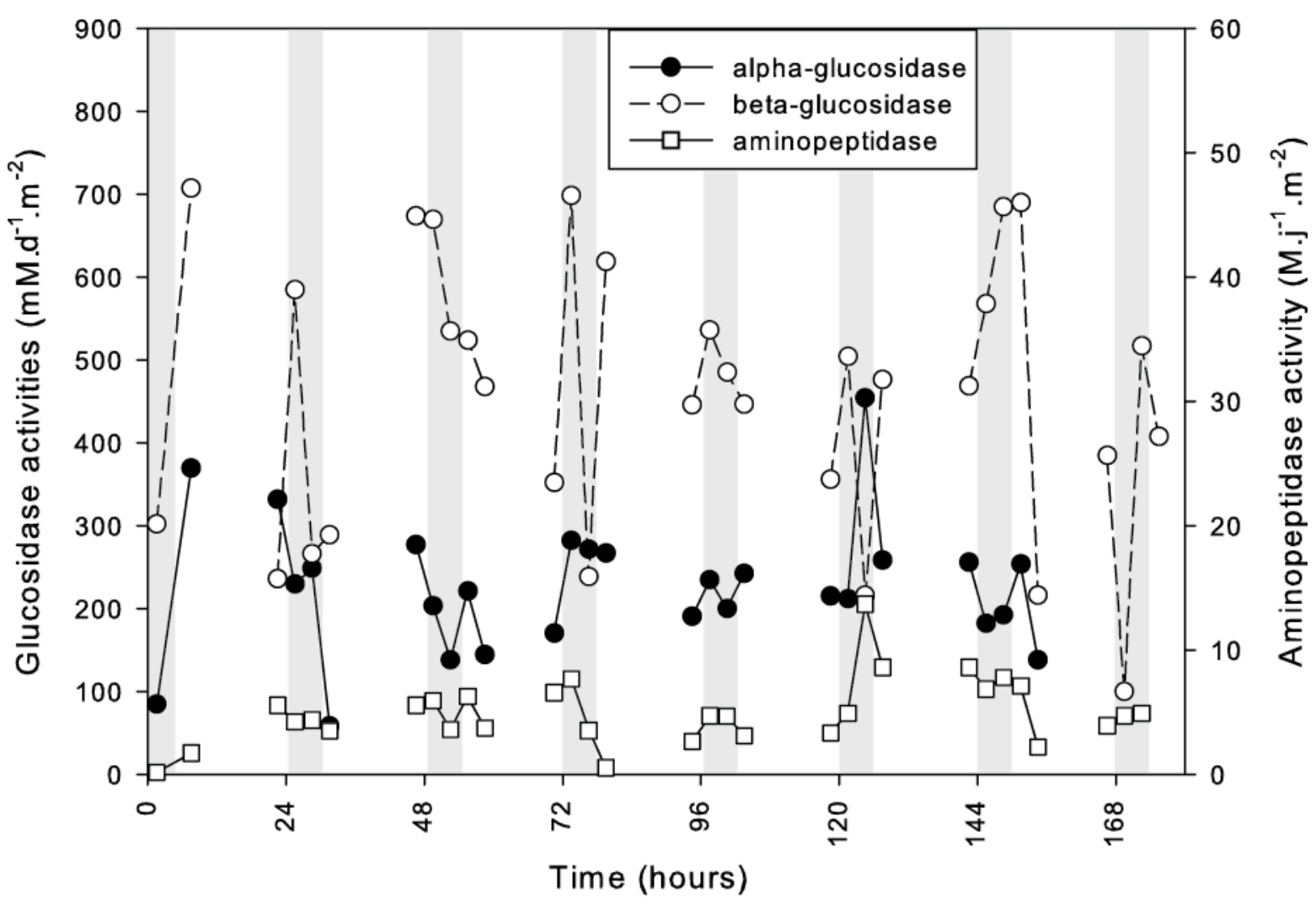

Figure 4 
A
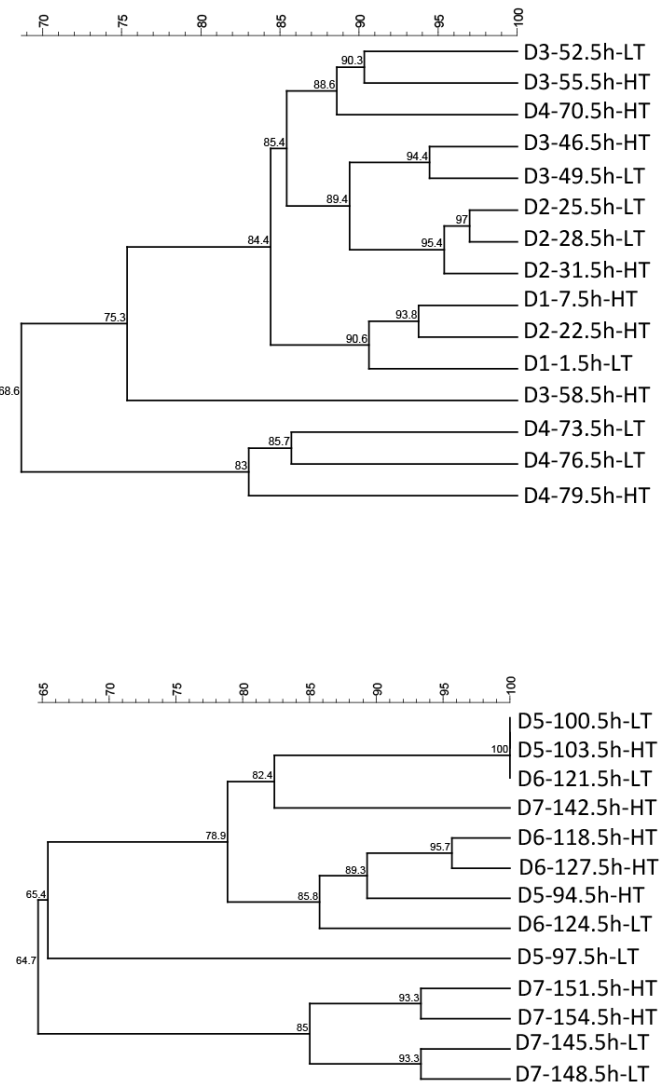

Figure 5 